\title{
Administration
}

\section{Designing and Managing Our Infrastructure for Success}

\author{
Mary Ellen Jeans, RN, PhD \\ Adjunct Professor, School of Nursing \\ Faculty of Health Sciences, University of Ottawa
}

The question posed to me was, "From a leader's perspective, what should change in nursing administration over the next five years?" The word "should" carries with it the connotation of some higher moral authority who must know what is best. This I cannot claim! However, I accepted the challenge.

One normally thinks of administration in relation to healthcare or academia. I wish to focus on leadership and administration of the nursing profession as a whole - how we organize ourselves and our infrastructure. The argument is that we should change how we are organized in order to gain a more strategic place in the health policy arena.

Over the past several years, nurse leaders have agreed unanimously that nursing needs to be a more prominent player, provincially and nationally, at the policy-making level. Although numerous reasons may be cited as to why this has not occurred, I believe a pivotal factor impeding our capacity as a profession to exert a more powerful influence on decision-making and policy development is related to our struggle to speak in one voice.

Policy-making is an incremental process requiring long-term commitment and long-standing relationships with governments and other stakeholder groups. In terms of nursing, it requires that our profession be organized in such a way that everyone knows who or what entity represents the entire discipline. You might say, we have strong voices for nursing who represent healthcare associations - unions, and so on. Precisely the point: to which voice will governments listen, if any? A very experienced deputy minister once asked me if I could draw a map of the organizations that represented nursing because his department could not figure out who was speaking for what topic and to whom they should go for information.

Our own infrastructure appears as a maze of different national and provincial/ 
territorial groups that, when one draws the map, make us look as if we are organized into small silos of specific interest. At the national level we have two major regulated groups that have very separate organizations representing them: registered nurses (RNs) and licensed practical nurses (LPNs). (In Ontario, LPNs are called RPNs.)

We also have a smaller group of registered psychiatric nurses (RPNs) who are licensed in the four western provinces and have their own organization. Such a picture raises the very serious question, "Does the discipline of nursing consist of one coherent body of knowledge, or is it indeed three different bodies of knowledge?" I would argue that nursing is one discipline, and that one may practise nursing at varying levels of knowledge and competency. Individuals should be able to move vertically and horizontally through different levels and fields of practice supported by a variety of educational programs. Regulating the three groups of nurses as one body would reduce the number of regulatory bodies by approximately 15 and no doubt reduce the confusion.

Another division is based on geography. Dividing ourselves on this basis has led to repetition within provinces and further repetition at the national level. Unfortunately, as our Canadian constitution established the boundaries of federal-provincial jurisdiction for healthcare, for obvious reasons this division is not likely to change in the near future.

Adding to the confusion is the phenomenon we see in Ontario, and possibly emerging in other provinces: that of the separation of the regulatory body from the professional association. We also have a large number of local, provincial and national unions representing the three regulated nursing groups. All these organizations claim to speak for nursing. However, history has shown that these nursing organizations (regulatory, professional and union) have often been in conflict with one another, leading to different voices giving opposing messages and further adding to a confusing and divisive professional infrastructure.

Add to the above array of groups speaking for nursing (or, perhaps more correctly, speaking for nurses and leaving the voice for nursing mute), there are more than 33 nursing specialty groups organized, in many instances, both provincially and nationally, around areas of clinical practice, education and research. Taken together, we have in Canada in excess of 100 organized entities claiming to speak for approximately 300,000 nurses. How can we seriously influence change at any level under these conditions? What should change? What will make us more credible in order to effect change at the level of policy?

Although it is unlikely that we can eliminate many of the current problems inherent in the existing infrastructure, one possible avenue exists - that of bringing all nursing groups under one roof. Over the past several years we have witnessed a number of attempts to work collaboratively among groups. Often, however, these efforts have been issue specific and time limited. Examples include occasions where the regulatory body and the union agreed on a 


\section{PROVIDENCE CONTINUING CAKE CENTRE many paths one mission}

it together; lobbying efforts to convince governments to invest in nursing; nursing and other healthcare organizations working together to defend the publicly funded healthcare system (e.g., HEAL, the Health Action Lobby), and so on.

Achievements such as the Nursing Research Fund and the Nursing Sector study - a human resource analysis for nursing - are just two examples of the success of such an approach at the federal level.

My vision of what "should" change in nursing administration transcends the usual definition of administration. It is a vision of change at the national level, at the level of our national association. My vision is that CNA's present role be transformed to a truly inclusive organization that brings together all the diverse voices of nursing. With thoughtful planning and sensitivity to the issues for all nurses, CNA could evolve into an umbrella organization (an association of associations) representing all aspects of nursing nationally. It would require a completely new governance structure, allowing for equality of voices and many more elected members. It would not be CNA as we know it today.

I am convinced we should make these changes now. The consequences of not speaking in one voice are serious - not only for the profession of nursing, but for the Canadian healthcare system as a whole.
PRONIDENCE CONTINUING CARE CENTRE(PCCC) aa leading provider of compasaionice, non wape heatrti care. and is affilused with Quevis Uvirnity. Treating each perion withreipect. dignty and compension, we ipecialize in corriplex continuing and long term care, geriatric and rehabititation progans, meral hedth sernon and palliative care Working at our Mental Health Services Site. candidates for the following pocitions will contribute to our odysey of care.

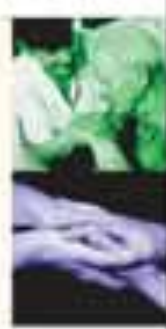

\section{CLINICAL NURSE SPECIALIST}

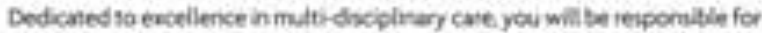
diving cononvous quainy improveovest and estabishing best practicen for delinery of care within our mental heath hospital Able to develop and conduct research prograns selated to the aveat of clinical practice, you will lesid and prionitise profestiorsl develocment intixives You wil determine and identify appeopriate performancer indicatons ta loster a collaborative leaming ewwinonment External participation and leaderihip in related problesional orgariations ademia and policy artrat will enutle you te eract a progresive vilion of care.

Qualified applicarts mil have a Mater's degree in Narsing with eleblity for comideration of an acadertic appointment wath Queeris 1Mvianity School of Nunine Regatration wath the College of Nusen of Ontavia a minimum of five years experience in a mental health serting and tamiliatity with prychosocil rehabiltration principies and recovery model phlescophy are also required. A patalonate edjacatoc your oritical thinking capubilities and results-oriented lapproach mill eneare your succest

\section{CLINICAL NURSE EDUCATOR}

in shis role your mandite wil be so facilitate cont invoas improvemect intiatives and the implementation of best practices for delvery of cave within mental

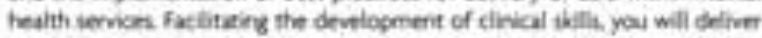
requed clinical training progatsk workshops and orientation llespoceble for

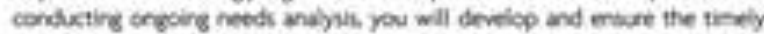
inplementacion of education and training intative itrahtepes as appropriate Coaching and mettorits thasing staft, you will monitor bey peformance

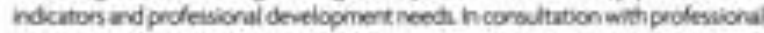
practice leaders the marugement. teants and other menbers of the muls-

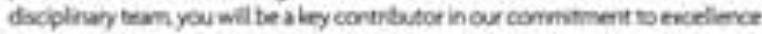
and a continuovi learning emiroment

To-qualfy you = It have a Bacheloridegee in Naning Science Materis degete peferred! segistration with the Collece of Nenes of Ontaria. condiderable nuning evperience in a mental heikth settine fourient certification in

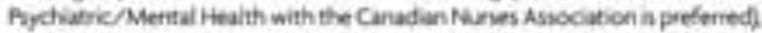
and a mumum of one yeur of clinical nune edxator experience la sombiration of education and prozressive clichical leddership rxperience may be consideredi As a seif-startec your strorg oral and witten commucation Wells enwble you to impure a commitment to continuos leamiks in other.

Meraliteaith Services astubet in Kington Ontario. in the heurt of the Thousand hlandh. Converiently located between Montreal and Toronto. Knsston boasti many amenities of a larket city tat with amall rown charm. Make the move to enjoy uncaulieled workife balahe with Rece

To apply for thene poiction. pleave forward your retume. euoting the position of interest to. HR Censultant.

Providence pcCC. Mental Health Services. Fare (619) S48-5sal.

Continuing Care Centre Mumanraouresamhspecechealkhint

For more ifformation on this and other opporturities. pleave viat one Web site at

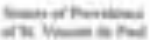

